\title{
KAJIAN PENERAPAN GOOD AGRICULTURAL PRACTICES (GAP) BAWANG MERAH DI NGANJUK DAN PROBOLINGGO
}

\section{STUDY ON THE APPLICATION OF GOOD AGRICULTURAL PRACTICES (GAP) SHALLOT IN NGANJUK AND PROBOLINGGO}

\author{
Baswarsiati $^{1)}$ dan Chendy Tafakresnanto ${ }^{1)}$ \\ ${ }^{1)}$ Balai Pengkajian Teknologi Pertanian Jawa Timur \\ Email: baswarsiati@gmail.com
}

\begin{abstract}
ABSTRAK
Era pasar bebas menghendaki produk yang aman konsumsi, bermutu dan diproduksi secara ramah lingkungan dengan harga yang relatif murah (bersaing). Kondisi ini mengharuskan adanya langkah kongkrit di tingkat petani/pelaku usaha, agar mampu memenuhi tuntutan tersebut. Salah satu kegiatan yang dapat dilakukan untuk mendukung hal tersebut adalah penerapan good agricultural practices (GAP). Untuk melakukan kajian penerapan GAP bawang merah, maka dilaksanakan pendampingan di kelompok tani dan demoplot di Desa Watu Wungkuk, Kecamatan Dringu, Kabupaten Probolinggo dan Desa Sukorejo, Kecamatan Rejoso, Kabupaten Nganjuk. Kegiatan dilaksanakan pada Januari-Desember 2016. Hasil tanaman bawang merah yang menggunakan pupuk organik 10 ton/ha ditambah Trichocompos mampu menekan serangan Fusarium sp. Dengan menerapkan GAP maka produksi bawang merah meningkat sekitar 8-10 \% dibandingkan cara budidaya eksisting. Hasil analisa usahatani bawang merah dengan pengendalian hama menggunakan insektisida kimia menghasilkan $\mathrm{B} / \mathrm{C}$ 2,55, dengan lampu perangkap menghasilkan $\mathrm{B} / \mathrm{C}$ 2,76 dan dengan kelambu kasa menghasilkan B/C 2,7.
\end{abstract}

Kata kunci: bawang merah; GAP; Nganjuk; penerapan; Probolinggo

\section{ABSTRACT}

The free market requires products that are safe for consumption, quality and environmentally friendly at a relatively cheap price (competitive). This condition requires concrete steps at the level of farmers/business, in order to meet these demands. One of the activities that can be done to support this is the application of Good Agricultural Practices (GAP). To study the application of shallot GAP in the form of assistance in farmer groups and demonstration plots in Watu Wungkuk village, Dringu sub-district, Probolinggo district and Sukorejo village, Rejoso subdistrict, Nganjuk district. The activity was carried out from January-December 2015. The shallot plant using 10 tons/ha of organic fertilizer plus Trichocompos was able to suppress Fusarium sp. By applying GAP, the production of shallots increases at around $8-10 \%$ compared to existing methods of cultivation. The results of analysis of shallot farming with pest control using chemical insecticides produced B/C 2.55 , with trap lights producing $B / C 2.76$ and with gauze nets producing $B / C 2.7$.

Key words: application; GAP; Probolinggo; Nganjuk; shallots 
PENDAHULUAN

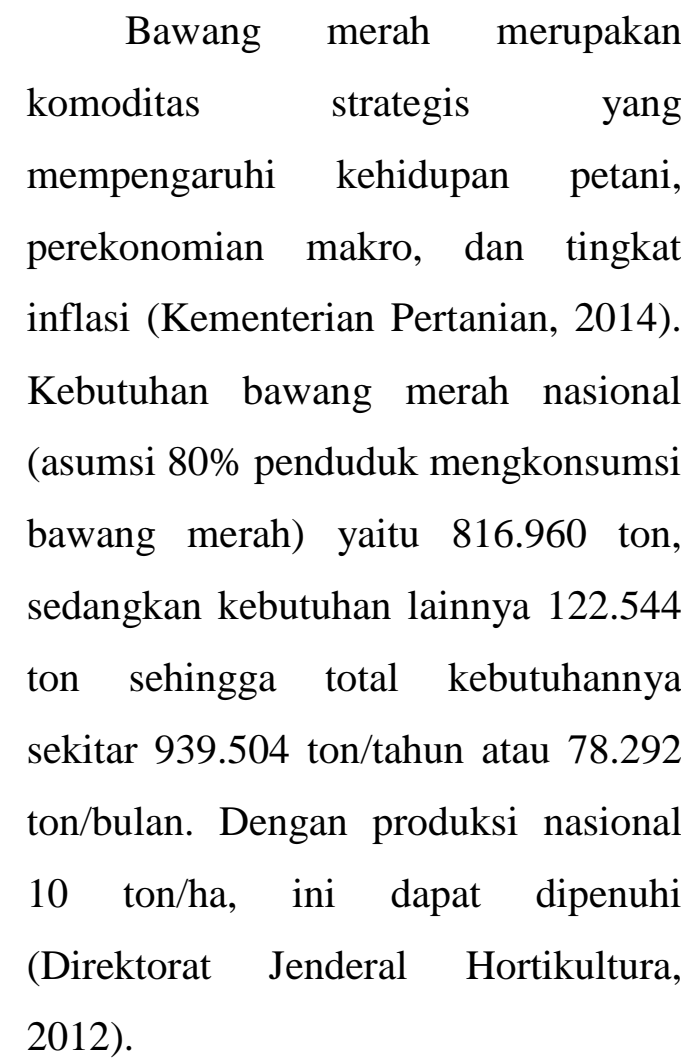

Produktivitas bawang merah di sentra produksi bawang merah di Nganjuk mencapai 15-18 ton/ha dan di Probolinggo 12-16 ton/ha (Dinas Pertanian Provinsi Jawa Timur, 2012). Produktivitas bawang merah di Jawa Timur dapat ditingkatkan dengan menerapkan Good Agriculture Practices (GAP). Tetapi standar GAP belum diterapkan di Jawa Timur termasuk di Nganjuk dan Probolinggo (Baswarsiati et al, 2009; 2012).
Keberhasilan usahatani bawang merah selain ditentukan oleh teknis budidaya khususnya dalam masalah OPT, juga ditentukan oleh varietas (Baswarsiati, et al., 2010), pengolahan lahan, pemupukan dan pemeliharaan tanaman yang intensif dan efisien serta pengelolaan pasca panen yang sesuai dan pemasaran (Baswarsiati, et al., 1998, Moekasan et al, 2010, Sastrosiswoyo, 1996).

Usahatani bawang merah memiliki resiko tinggi dalam budidaya, seperti serangan OPT yang dapat menggagalkan panen (Moekasan et al, 2013). Produktivitas yang rendah dan serangan OPT umumnya meningkat pada pertanaman di luar musim atau waktu off-season. Menurut Udiarto, et al. (2005) dan Setiawati, et al. (2005) kehilangan hasil oleh serangan OPT pada tanaman bawang merah berkisar 20-100\%. OPT utama pada tanaman bawang merah yaitu ulat bawang Spodoptera exigua (Moekasan, et al., 2012, Hadisoeganda, et al., 1995). Sedangkan penyakit seperti Fusarium, Alternaria dan Antraknose semakin 
tinggi di musim hujan, sehingga gagal panen sering terjadi pada musim hujan. Hal ini akibat kelembaban udara lebih tinggi dibandingkan musim kemarau sehingga intensitas serangan penyakit lebih tinggi. Sedangkan pada musim kemarau suhu udara lebih tinggi dibandingkan musim hujan sehingga intensitas serangan hama lebih tinggi dibandingkan intensitas serangan penyakit (Duriat, et al., 1997, Rosmahani, et al., 1998 dan 2001).

Petani di sentra produksi bawang merah di Nganjuk maupun Probolinggo masih banyak yang belum menerapkan GAP walaupun setiap kabupaten telah memiliki SOP budidaya bawang merah. Era pasar bebas menghendaki produk yang aman konsumsi, bermutu dan ramah lingkungan dengan harga yang relatif murah (bersaing). Kondisi ini mengharuskan adanya langkah kongkrit di tingkat petani/pelaku usaha, agar mampu memenuhi tuntutan tersebut. Salah satu kegiatan untuk mendukung hal tersebut adalah penerapan GAP yang diawali dengan Sekolah Lapang Good Agricultural Practices (SL-GAP). Dalam SL-GAP akan dipraktekkan norma dan cara budidaya sayuran dan tanaman obat (termasuk bawang merah) yang baik, mengacu kepada Permentan No. 48/2009 dan Permentan No. 57/2012, Pedoman Pelaksanaan Sekolah Lapangan dan acuan teknis seperti SOP spesifik komoditas dan spesifik lokasi (Dirjen Hortikultura, 2014).

Untuk itu perlu dilakukan kajian dan pendampingan penerapan GAP bawang merah di sentra produksi Nganjuk dan Probolinggo, Jawa Timur untuk meningkatkan teknis budidaya di tingkat petani serta memperbaiki aspek budidaya dan perbaikan kualitas bawang merah milik petani.

\section{METODE PENELITIAN}

Penerapan GAP bawang merah dilaksanakan di Kabupaten Probolinggo dan Kabupaten Nganjuk. Pendampingan dilaksanakan JanuariDesember 2016. Untuk melihat keragaan hasil penerapan GAP bawang merah di Probolinggo dan Nganjuk, dilakukan kegiatan demoplot serta pendampingan intensif di tingkat kelompok tani di kedua kabupaten tersebut. 
Tabel 1. Teknologi Sesuai SOP GAP Bawang Merah spesifik lokasi Nganjuk dan Probolinggo yang diterapkan pada demoplot

\begin{tabular}{|c|c|c|c|}
\hline No & Teknologi & Kabupaten Nganjuk & Kabupaten Probolinggo \\
\hline 1 & Pengolahan lahan & $\begin{array}{l}\text { Lahan diolah hingga gembur dan } \\
\text { dibuat bedengan dengan lebar } 180 \\
\mathrm{~cm} \text {, tinggi } 40 \mathrm{~cm} \text {, panjang sesuai } \\
\text { kondisi lahan. Jarak antar bedengan } \\
40 \mathrm{~cm} \text {, kedalaman parit } 50 \mathrm{~cm}\end{array}$ & $\begin{array}{l}\text { Lahan diolah hingga gembur dan } \\
\text { dibuat bedengan dengan lebar } 180 \\
\mathrm{~cm} \text {, tinggi } 40 \mathrm{~cm} \text {, panjang sesuai } \\
\text { kondisi lahan. Jarak antar bedengan } \\
40 \mathrm{~cm} \text {, kedalaman parit } 50 \mathrm{~cm}\end{array}$ \\
\hline 2 & Jarak tanam & $20 \mathrm{~cm} \mathrm{x} 15 \mathrm{~cm}$ & $20 \mathrm{~cm} \mathrm{x} 15 \mathrm{~cm}$ \\
\hline 3 & Varietas & $\begin{array}{l}\text { - Varietas existing Tajuk } \\
\text { - Varietas unggul nasional lainnya } \\
\text { sebagai pembanding dan } \\
\text { substitusi yaitu Rubaru (asal } \\
\text { Sumenep) dan Batu Ijo (asal } \\
\text { Malang) }\end{array}$ & $\begin{array}{l}\text { - Varietas existing Biru Lancor } \\
\text { - Varietas unggul nasional lainnya } \\
\text { sebagai pembanding dan } \\
\text { substitusi yaitu Rubaru (asal } \\
\text { Sumenep) dan Batu Ijo (asal } \\
\text { Malang) }\end{array}$ \\
\hline 4 & $\begin{array}{l}\text { Pupuk organik } \\
\text { (sesuai SOP) }\end{array}$ & $\begin{array}{l}\text { Pupuk organik } 10 \text { ton/ha dengan } \\
\text { tambahan Trichocompos } 15 \mathrm{~kg} / \mathrm{ha}\end{array}$ & $\begin{array}{l}\text { Pupuk organik } 10 \text { ton/ha dengan } \\
\text { tambahan Trichocompos } 15 \mathrm{~kg} / \mathrm{ha}\end{array}$ \\
\hline 5 & Pupuk anorganik & $\begin{array}{l}\text { - SP } 36150 \mathrm{~kg} / \mathrm{ha} \text { (sebagai pupuk } \\
\text { dasar) pada } 7 \text { hari sebelum tanam } \\
\text { - NPK } 300 \mathrm{~kg} / \mathrm{ha} \\
\text { + Urea } 100 \mathrm{~kg} / \mathrm{ha} \\
\text { + ZA } 250 \mathrm{~kg} / \mathrm{ha} \text { diberikan masing- } \\
\text { masing separuh dosis pada } 15 \\
\text { dan } 30 \text { hari setelah tanam }\end{array}$ & $\begin{array}{l}\text { - SP } 36150 \mathrm{~kg} / \mathrm{ha} \text { (sebagai pupuk } \\
\text { dasar) pada } 7 \text { hari sebelum tanam } \\
\text { - NPK } 300 \mathrm{~kg} / \mathrm{ha} \\
\text { + Urea } 100 \mathrm{~kg} / \mathrm{ha} \\
+ \text { ZA } 250 \mathrm{~kg} / \mathrm{ha} \text { diberikan masing- } \\
\text { masing separuh dosis pada } 15 \mathrm{dan} \\
\text { 30 hari setelah tanam }\end{array}$ \\
\hline 6 & $\begin{array}{l}\text { Pengendalian } \\
\text { OPT }\end{array}$ & $\begin{array}{l}\text { Light trap tenaga surya dan yellow } \\
\text { trap untuk hama dan Trichocompos } \\
\text { untuk Fusarium }\end{array}$ & $\begin{array}{l}\text { Kelambu dari jaring nilon untuk } \\
\text { hama dan Trichocompos untuk } \\
\text { Fusarium }\end{array}$ \\
\hline 7 & Pengairan & $\begin{array}{l}\text { Dengan di "leb" (digenangi sampai } \\
\text { kapasitas lapang) dan disirat }\end{array}$ & $\begin{array}{l}\text { Dengan di "leb" (digenangi sampai } \\
\text { kapasitas lapang) dan disirat }\end{array}$ \\
\hline
\end{tabular}

Lokasi demoplot masing-masing di desa Watu Wungkuk, Kecamatan Dringu, Kabupaten Probolinggo dan Desa Sukorejo, Kecamatan Rejoso, Kabupaten Nganjuk. Persyaratan kesesuaian lokasi untuk bawang merah ditentukan oleh kelembaban, tekstur, struktur dan kesuburan tanah. Secara umum tanaman bawang merah memerlukan bulan kering 4-5 bulan, curah hujan 1000-1500 mm/th, suhu sekitar $25-32{ }^{\circ} \mathrm{C}, \mathrm{pH}$ tanah 5,5-6,5, lahan tidak ternaungi, drainase dan kesuburan baik, tekstur lempung berpasir dan struktur tanah remah (Sumarni, et al., 1995).

Pelaksanaan pendampingan dan kegiatan demoplot dilakukan secara partisipatif melibatkan anggota kelompok tani dari lokasi terpilih. 
Selain itu dilakukan penggalian data kondisi eksisting dari kawasan pengembangan bawang merah dengan menggali data KKP (Kajian Kebutuhan dan Peluang) dari informan kunci dan pemangku kepentingan yaitu Dinas Pertanian Kabupaten, Badan Ketahanan Pangan dan Pelaksana Penyuluhan, BPP, aparat Kecamatan dan Desa serta dari Penyuluh Pertanian Lapangan, Petugas Pengamat Hama dan Kelompok Tani serta Gapoktan. Adapun teknologi sesuai Standar Operasional Prosedur (SOP) bawang merah spesifik lokasi yang diterapkan dalam demoplot di Nganjuk dan Probolinggo disajikan pada Tabel 1.

Parameter pengamatan meliputi tinggi tanaman, jumlah daun, jumlah anakan, produksi/hektar juga serangan Spodoptera exigua, Alternaria dan Fusarium sebagai OPT utama bawang merah.

\section{HASIL DAN PEMBAHASAN}

Berbagai kendala terkait upaya meningkatkan produksi, mutu dan daya saing produk hortikultura termasuk bawang merah perlu disikapi dengan pendekatan pengembangan secara terpadu. Enam pilar pengembangan hortikultura merupakan fokus kegiatan prioritas yang dilaksanakan secara simultan dan terintegrasi antara Pusat, Provinsi dan Kabupaten dalam memfasilitasi dan mempermudah akses swasta/ pengusaha dalam mengembangkan hortikultura (Dirjen Hortikultura, 2008). Salah satu bagian dari enam pilar tersebut adalah penerapan norma budidaya yang baik atau penerapan GAP dalam berbudidaya termasuk budidaya bawang merah. Hingga saat ini kedua kabupaten sentra produksi bawang merah di Jawa Timur yaitu Nganjuk dan Probolinggo telah memiliki SOP budidaya bawang merah spesifik lokasi sesuai tata aturan di dalam GAP namun belum semua petani menerapkan SOP tersebut.

Beberapa masalah yang menyebabkannya antara lain: 1) Petani masih ragu apakah SOP budidaya bawang merah spesifik lokasi akan menjamin produktivitas, 2) Serangan OPT yang tinggi menjadi penentu untuk bersikap menerapkan SOP atau tetap melakukan budidaya eksisting yang dilakukan petani, 3) petani masih 
meragukan keberhasilan penerapan teknologi ramah lingkungan, karena terlalu lama menggunakan pupuk kimia dan pestisida kimia, 4) Petani perlu membuktikan keberhasilan SOP dibandingkan cara petani. Oleh karena itu diperlukan pembuktian melalui demoplot teknologi dan penerapan GAP di tingkat kelompok tani atau Gapoktan dan dikawal pelaksanaannya (Baswarsiati et al, 2015).

Dari tahun 2015 di 5 kabupaten yaitu Nganjuk, Probolinggo, Bangkalan, Pamekasan dan Sumenep (Baswarsiati et al, 2015) disimpulkan bahwa:1) Ppendampingan penerapan GAP dan GHP di kawasan bawang merah perlu dilakukan kontinyu dan berkelanjutan karena belum banyak petani bawang merah menerapkan teknologi dengan benar, 2) Pengenalan varietas unggul di luar varietas existing diperlukan sebagai salah satu substitusi varietas dan direspon baik oleh kelompok tani. Varietas unggul Badan Litbang Pertanian asal Balai Penelitian Sayuran belum dapat diterima petani karena kondisi di lapang kurang baik, 3) Varietas unggul di Jawa Timur seperti Batu Ijo,
Rubaru, Bauji, Biru Lancor dapat digunakan untuk substitusi varietas di sentra produksi lainnya karena mudah beradaptasi dan mampu berproduksi dengan baik. Hal ini akan mengurangi resiko keterbatasan benih dan harga yang tinggi, 4) Produksi bawang merah hasil demoplot lebih tinggi 20$30 \%$ dibandingkan cara petani karena menggunakan tambahan pupuk organik sebanyak 10 ton/ha serta efisiensi dalam penggunaan pestisida kimia, 5) Petani meningkat pengetahuannya serta pemahamannya tentang budidaya bawang merah yang baik sesuai GAP sehingga produksi bawang merah meningkat sekitar 10$20 \%$.

\section{Kondisi Eksisting Usahatani Bawang Merah di Nganjuk dan Probolinggo}

\section{Kawasan Bawang Merah di Kabupaten Nganjuk}

Perkembangan bawang merah di kabupaten Nganjuk cukup pesat. Areal tanam tahun 2008 adalah 5.250 ha, tahun 2010 seluas 10.300 ha dan 2015 mencapai 11.785 ha. Beberapa varietas unggul nasional yang sudah dilepas 
berasal dari Nganjuk antara lain: Bauji dan Super Philip (dilepas atas usulan BPTP Balitbangtan Jawa Timur), Tajuk (dilepas atas usulan Pemerintah Kabupaten Nganjuk dan Institut Pertanian Bogor), Katumi dan Mentes (dilepas atas usulan Balai Penelitian Tanaman Sayuran dan petani setempat).

Bawang merah ditanam sepanjang musim sampai lima kali per tahun. Hal ini tidak dianjurkan, tetapi karena dapat menjamin penyediaan benih melalui jalur benih antar lapang dan antar musim (Jabalsim) maka pola tanam ini perlu dipertahankan.

Produktivitas bawang merah di kabupaten Nganjuk pada musim penghujan (off season) berkisar 8-12 ton/ha. Sedangkan di musim kemarau, berkisar antara 14,5-24 ton/ha. Pada daerah tertentu yaitu di desa Sidokare dan Mojorembun, kecamatan Rejoso, Nganjuk mampu mencapai 25 ton/ha. Tetapi peningkatan produksi yang tinggi masih menggunakan pestisida kimia berlebihan dan belum menerapkan konsep PHT (Diperta Nganjuk, 2015).
Beberapa petani bawang merah di Nganjuk mampu menghasilkan bawang merah kualitas Prima 3 (produk aman dikonsumsi) dan seorang petani telah menerapkan Europe GAP. Tetapi pasar masih belum peduli, menerapkan GAP atau tidak produknya dihargai dengan harga sama. Hal ini yang menyebabkan petani enggan menerapkan GAP. (Diperta Provinsi Jawa Timur, 2015).

Pelaksanaan tanam bawang merah di kabupaten Nganjuk telah dilakukan serempak pada setiap kawasan sehingga pengendalian hama dan penyakit lebih mudah dan keberhasilan lebih terjamin jika menerapkan PHT. Teknologi yang dikuasai oleh petani Nganjuk pada umumnya lebih baik dan lebih maju dibanding petani di sentra produksi lain di Jawa Timur. Tetapi beberapa petani masih menggunakan pestisida kimia.

Beberapa kawasan bawang merah sudah menggunakan light trap tenaga surya maupun PLN untuk mengendalikan serangan Spodotera exigua. Alat ini buatan kelompok tani dari Nganjuk dan sudah 
diperjualbelikan di luar kabupaten. Selain itu petani juga sudah menggunakan perangkap likat kuning untuk pengendalian Lyriomiza sp secara serentak. Demikian juga penggunaan biopestisida nabati sudah dilakukan oleh petani Nganjuk dan sekitar 4-5 kelompok tani maju telah membuat pestisida nabati sendiri dengan didampingi petugas setempat.

Kelompok tani yang terlibat di lokasi demoplot BPTP Jawa Timur yaitu KT Margo Makmur, desa Sukorejo, kecamatan Rejoso, Nganjuk dengan ketua Bapak Sorbaah. Secara umum dari hasil diskusi awal dapat diketahui kemampuan anggota kelompok tani untuk berbudidaya bawang merah sudah baik hanya saja perlu pengarahan efisiensi penggunaan pupuk kimia dan mengurangi pestisida kimia dengan budidaya ramah lingkungan serta memperkenalkan manfaat Trichoderma dan penggunaan yellow trap.

\section{Kawasan Bawang Merah Kabupaten Probolinggo}

Kabupaten Probolinggo merupakan sentra produksi bawang merah kedua di Jawa Timur setelah Nganjuk. Luas areal panen bawang merah di Probolinggo tahun 2014 yaitu 7.155 ha dengan produksi $514.086 \mathrm{ku}$ dan luas areal tanam hingga Mei 2015 yaitu 2.931 ha. Petani bawang merah di Probolinggo belum melaksanakan penanaman serempak seperti di kabupaten Nganjuk. Puncak penanaman terjadi pada bulan Mei, Juni dan Juli. Pola penanaman bawang merah seperti ini akan menjamin kontinyuitas produksi sehingga persediaan bawang merah di Probolinggo selalu terjamin. Tetapi dari konsep PHT pola tanam tidak serentak tidak disarankan.

Dari 24 kecamatan di Probolinggo, maka 16 kecamatan adalah wilayah bawang merah dengan 4 kecamatan sebagai sentra utama. Areal tanam terluas hingga Mei 2015 di kecamatan Dringu (337 ha), Tegal Siwalan (334 ha), Leces (247 ha) dan Gending (139 ha). Sedangkan luas areal tanam tahun 2014 di kecamatan Dringu (2.695 ha), Tegal Siwalan (1.793 ha), Leces (1.028 ha), Gending (880 ha) (Diperta Kabupaten Probolinggo, 2015). 
Panen bawang merah tertinggi dicapai oleh Kecamatan Dringu, yaitu $171.719 \mathrm{ku}$ dengan panen seluas 2.803 ha. Kecamatan lain yang berkontribusi besar dalam produksi bawang merah di Kabupaten Probolinggo adalah Tegalsiwalan, Leces, Gending, dan Banyuanyar. Daerah yang produksinya sedikit antara lain Kraksaan dan Wonomerto.

Varietas yang berkembang di Probolinggo yaitu Biru Lancor yang merupakan hasil seleksi dan pemurnian varietas lokal asal Probolinggo yang dilakukan oleh BPTP Jawa Timur bekerjasama dengan Dinas Pertanian Provinsi Jawa Timur, Dinas Pertanian Kabupaten Probolinggo dan petani. Hampir 95\% luas areal bawang merah di Probolinggo ditanami varietas tersebut dan juga berkembang di luar propinsi Jawa Timur seperti Gorontalo, Jogja, Sulawesi Selatan dan provinsi lainnya (Diperta Kabupaten Probolinggo, 2015). Potensi produksi Varietas Biru Lancor pada MK I (tanam bulan April, Mei) sekitar 8-10 ton/ha dan pada MK II (tanam bulan Juni, Juli bersamaan dengan adanya "angin Gending") sekitar 15-18 ton/ha.

Bawang merah varietas Biru Lancor memilik perkembangan pesat. Sejak dilepas tahun 2009 sudah diproduksi sekitar 275 ton. Hal ini tertinggi dibandingkan varietas lainnya yaitu Super Philip (16 ton), Monjung (4 ton), Bauji (3 ton), Ilocos (1 ton). Distribusi benih varietas Biru Lancor sudah menyebar ke Jogja, Enrekang, Gorontalo dan Kalimantan.

Varietas yang berkembang di Probolinggo didominasi oleh Biru Lancor karena lebih toleran terhadap OPT, lebih adaptif dan cocok untuk bawang goreng karena lebih renyah dan aroma kuat (Diperta Kabupaten Probolinggo, 2015).

Inovasi budidaya bawang merah yang diaplikasikan di antaranya: penggunaan varietas Biru Lancor, pengendalian hama dan penyakit sesuai konsep PHT, penggunaan net (kelambu) untuk pengendalian Spodoptera exigua, pemupukan spesifik lokasi dan penanganan pasca panen yang tepat.

Penggunaan net (kelambu) merupakan spesifik lokasi budidaya 
bawang merah di Probolinggo. Dengan net maka efisiensi biaya usahatani berkurang 30-40\% terutama pestisida kimia (Baswarsiati, et al., 2016).

Kelompok tani yang terlibat di lokasi demoplot BPTP Jawa Timur yaitu Kelompok Tani Tunas Jaya, Desa Watuwungkuk, Kecamatan Dringu, Probolinggo dengan Ketua Bapak Mohamad Santoso. Kemampuan anggota kelompok tani berbudidaya bawang merah sudah baik, tetapi perlu pengarahan efisiensi penggunaan pupuk kimia, meningkatkan penggunaan pupuk organik, mengurangi pestisida kimia, memperkenalkan manfaat

Trichoderma dan yellow trap.

\section{Keragaan Hasil Demoplot}

Keragaan hasil demoplot untuk varietas Rubaru dan Batu Ijo yang diperkenalkan ke wilayah kabupaten Nganjuk dan Probolinggo disajikan pada tabel 2-7.
Tabel 2. Keragaan tanaman bawang merah varietas unggul Rubaru dan serangan Spodoptera exigua, Alternaria dan Fusarium di Nganjuk 2016.

\begin{tabular}{lccc}
\hline Keragaan & \multicolumn{3}{c}{ Umur tanaman } \\
& (hari) & \\
\cline { 2 - 4 } & 30 & 40 & 50 \\
\hline Tinggi tanaman (cm) & 36,5 & 44,4 & 45,4 \\
Jumlah anakan & 8,0 & 9,5 & 9,1 \\
Jumlah daun & 41,0 & 41,9 & 43,5 \\
Serangan Spodop-tera & 0,0 & 10,0 & 10,0 \\
exigua (\%) & & & \\
Serangan Alternaria (\%) & 0,0 & 10,0 & 10,0 \\
Serangan Fusarium (\%) & 0,0 & 2,0 & 2,0 \\
\hline Produksi/ha (ton) & 14,9 & & \\
\hline
\end{tabular}

Tabel 3. Keragaan tanaman bawang merah varietas unggul Batu Ijo dan serangan Spodoptera exigua, Alternaria dan Fusarium di Nganjuk 2016

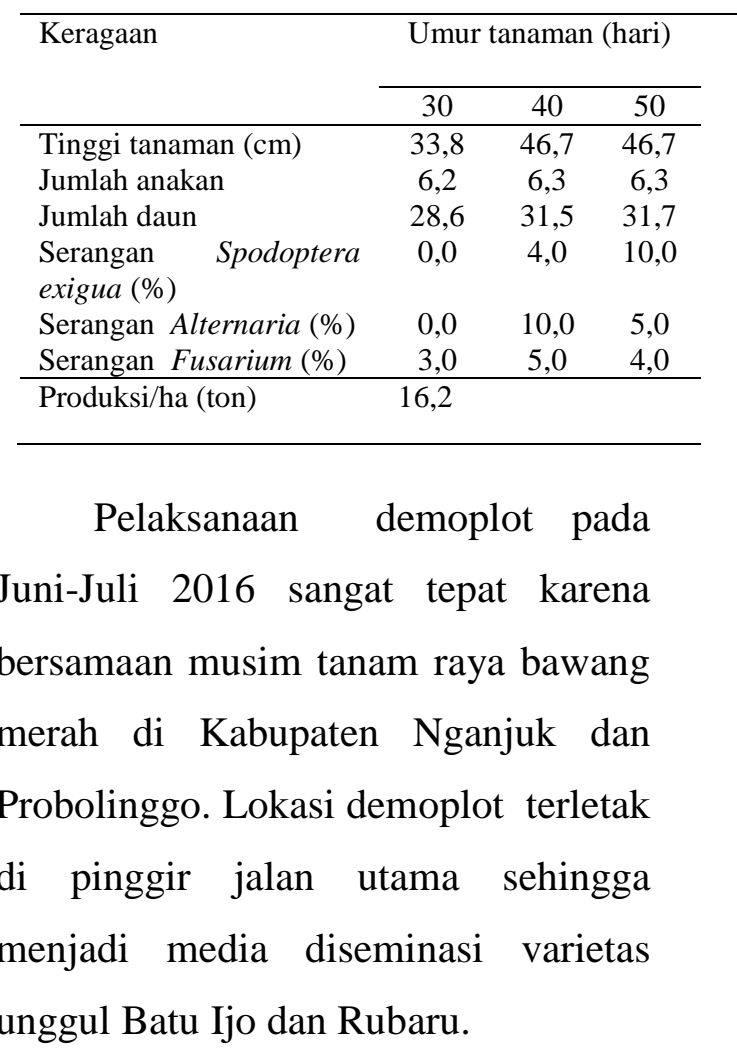


Tabel 4. Keragaan tanaman bawang merah varietas unggul Tajuk dan persentase serangan ulat bawang (Spodoptera exigua) serta penyakit Alternaria dan Fusarium Nganjuk 2016.

\begin{tabular}{lccc}
\hline Keragaan & \multicolumn{3}{c}{ Umur tanaman (hari) } \\
\cline { 2 - 4 } & 30 & 40 & 50 \\
\hline Tinggi tanaman (cm) & 34,5 & 43,2 & 45,6 \\
Jumlah anakan & 6,6 & 7,3 & 8,5 \\
Jumlah daun & 30,2 & 33,6 & 38,7 \\
Serangan $\quad$ Spodoptera & 0,0 & 5,0 & 10,0 \\
exigua (\%) & & & \\
Serangan Alternaria (\%) & 0,0 & 8,0 & 0,0 \\
Serangan Fusarium (\%) & 0,0 & 4,0 & 3,0 \\
Produksi/ha (ton) & 17,4 & & \\
\hline
\end{tabular}

Keterangan:

Produktivitas bawang merah varietas Tajuk milik petani di sekitar demoplot berkisar 16,016,5 ton/ha yang tidak menerapkan GAP.

Dari hasil demoplot di Nganjuk Batu Ijo mampu tumbuh dengan baik dan memiliki jumlah anakan lebih dari 6. sehingga di masa depan dapat digunakan sebagai substitusi varietas karena pemeliharaannya mudah dan umbinya besar. Sedangkan varietas Rubaru pertumbuhan baik tetapi petani kurang tertarik karena pertumbuhnnya kurang bagus dibanding varietas Thailand Nganjuk (Tajuk) yang sudah beradaptasi lama di Nganjuk (Baswarsiati, et al., 2015).
Tabel 5. Keragaan tanaman bawang merah varietas unggul Rubaru dan serangan Spodoptera exigua, Alternaria dan Fusarium di Probolinggo 2016

\begin{tabular}{lccc}
\hline Keragaan & \multicolumn{3}{c}{ Umur tanaman (hari) } \\
\cline { 2 - 4 } & 30 & 40 & 50 \\
\hline Tinggi tanaman (cm) & 25,0 & 29,4 & 35,6 \\
Jumlah anakan & 7,2 & 8,5 & 9,1 \\
Jumlah daun & 32,9 & 34,5 & 43,5 \\
Serangan Spodop-tera & 11,8 & 6,0 & 14,5 \\
exigua (\%) & & & \\
Serangan Alternaria (\%) & 2,0 & 6,0 & 2,0 \\
Serangan Fusarium (\%) & 0,0 & 2,0 & 3,0 \\
\hline Produksi/ha (ton) & 14,5 & & \\
\hline
\end{tabular}

Hasil demoplot di Probolinggo menunjukkan Batu Ijo yang mampu tumbuh dengan baik di Probolinggo. Hal ini dapat menjadi alternatif lain varietas di Probolinggo, sementara Rubaru kurang menarik bagi petani.

Tabel 6. Keragaan tanaman bawang merah varietas unggul Batu Ijo dan serangan Spodoptera exigua, Alternaria dan Fusarium di Probolinggo 2016

\begin{tabular}{lccc}
\hline Keragaan & \multicolumn{3}{c}{ Umur } \\
& 30 & 40 & 50 \\
\hline Tinggi tanaman (cm) & 27,5 & 32,1 & 43,2 \\
Jumlah anakan & 5,8 & 6,1 & 6,5 \\
Jumlah daun & 26,4 & 28,5 & 31,7 \\
Serangan $\quad$ Spodoptera & 12,6 & 5,7 & 31,8 \\
exigua (\%) & & & \\
Serangan Alternaria (\%) & 4,0 & 6,0 & 5,0 \\
Serangan Fusarium (\%) & 3,0 & 7,0 & 5,0 \\
Produksi/ha (ton) & 15,2 & & \\
\hline
\end{tabular}


Analisa Usaha Tani

Tabel 7. Analisa Usahatani Bawang Merah dengan Beberapa Cara Pengendalian OPT di Nganjuk dan Probolinggo 2016

\begin{tabular}{|c|c|c|c|c|c|c|}
\hline \multirow[t]{3}{*}{ Uraian } & \multicolumn{6}{|c|}{ Cara Pengendalian Hama } \\
\hline & \multicolumn{2}{|c|}{ Pestisida Kimia } & \multicolumn{2}{|c|}{ Lampu Perangkap } & \multicolumn{2}{|c|}{ Kelambu Kasa } \\
\hline & Fisik (kg) & $\begin{array}{c}\text { Nilai } \\
\text { dalam } \\
\text { Ribu Rp. }\end{array}$ & Fisik (kg) & Nilai (Rp.) & Fisik (kg) & Nilai (Rp.) \\
\hline Sewa Lahan & 1 ha & 10.000 & 1 ha & 10.000 .000 & 1 ha & 10.000 .000 \\
\hline Benih & 1200 & 48.000 & 1.200 & 48.000 .000 & 1.200 & 48.000 .000 \\
\hline SP 36 & 200 & 440 & 200 & 440.000 & 200 & 440.000 \\
\hline Urea & 100 & 180 & 100 & 180.000 & 100 & 180.000 \\
\hline $\mathrm{ZA}$ & 250 & 975 & 250 & 975.000 & 250 & 975.000 \\
\hline NPK & 300 & 2.610 & 300 & 2.610 .000 & 300 & 2.610 .000 \\
\hline Pestisida & 60 & 9.000 & 15 & 2.250 .000 & 10 & 1.500 .000 \\
\hline $\begin{array}{l}\text { Lampu perangkap/ } \\
\text { musim tanam }\end{array}$ & - & & 30 titik & 2.500 .000 & - & \\
\hline $\begin{array}{l}\text { Bahan kelambu } \\
\text { nilon/musim tanam }\end{array}$ & - & & - & & 1 paket & 3.500 .000 \\
\hline Pupuk organik & 10.000 & 5.000 & 10.000 & 5.000 .000 & 10.000 & 5.000 .000 \\
\hline Trichocompos & 15 & 150 & 15 & 150.000 & 15 & 150.000 \\
\hline $\begin{array}{l}\text { Tenaga Kerja } \\
\text { Olah tanah }\end{array}$ & 120 & 3.000 & 120 & 3.000 .000 & 120 & 3.000 .000 \\
\hline Membersihkan benih & 12 & 300 & 12 & 300.000 & 12 & 300.000 \\
\hline Tanam & 33 & 825 & 33 & 825.000 & 33 & 825.000 \\
\hline Penyiangan & 45 & 1.125 & 45 & 1.125 .000 & 45 & 1.125 .000 \\
\hline Perbaikan drainase & 10 & 250 & 10 & 250.000 & 10 & 250.000 \\
\hline Pemupukan & 12 & 300 & 12 & 300.000 & 12 & 300.000 \\
\hline Penyemprotan & 60 & 1.500 & 15 & 375.000 & 10 & 250.000 \\
\hline Panen & 35 & 875 & 40 & 1.000 .000 & 40 & 1.000 .000 \\
\hline Total Biaya & & 84.530 & & 79.730 .000 & & 79.405.000 \\
\hline Harga Jual & & 20 & & 20.000 & & 20.000 \\
\hline Hasil Panen & 15.000 & & 15.000 & & 15.000 & \\
\hline Penerimaan & & 300.000 & & 300.000 .000 & & 300.000 .000 \\
\hline Pendapatan & & 215.470 & & 220.270 .000 & & 220.595 .000 \\
\hline $\mathrm{B} / \mathrm{C}$ ratio & & 2,55 & & 2,76 & & 2,77 \\
\hline
\end{tabular}


Tabel 8. Keragaan tanaman bawang merah varietas unggul Biru Lancor dan serangan Spodoptera exigua, Alternaria dan Fusarium di Probolinggo 2016

\begin{tabular}{|c|c|c|c|}
\hline \multirow[t]{2}{*}{ Keragaan } & \multicolumn{3}{|c|}{ Umur tanaman (hari) } \\
\hline & 30 & 40 & 50 \\
\hline Tinggi tanaman $(\mathrm{cm})$ & 35,5 & 42,2 & 45,6 \\
\hline Jumlah anakan & 6,8 & 7,2 & 8,4 \\
\hline Jumlah daun & 30,3 & 33,4 & 38,5 \\
\hline $\begin{array}{l}\text { Serangan } \\
\text { exigua }(\%)\end{array}$ & 12,3 & 16,7 & 20,80 \\
\hline Serangan Alternaria $(\%)$ & 4 & 6 & 2 \\
\hline Serangan Fusarium (\%) & 2 & 3 & 3 \\
\hline Produksi/ha (ton) & 16,4 & & \\
\hline
\end{tabular}

Keterangan: Produktivitas Biru Lancor hasil petani di luar demoplot berkisar 14-15 ton/ha yang tidak menerapkan GAP.

Di Probolinggo varietas Biru Lancor hasil demoplot meningkat sekitar $10 \%$ dibanding dengan hasil petani sekitar. Varietas Rubaru dan Batu Ijo beradaptasi dengan baik di Nganjuk walaupun produksinya masih lebih rendah dibanding varietas Tajuk.

Pengendalian hama penyakit pada demoplot menggunakan insektisida kimia, lampu perangkap, dan kelambu kasa menghasilkan B/C berturut-turut sebesar 2,55;2,76 dan 2,77. Nilai $\mathrm{B} / \mathrm{C}>1$ menunjukkan bahwa cara pengendalian tersebut layak diterapkan.

\section{KESIMPULAN DAN SARAN}

\section{Kesimpulan}

Penggunaan pupuk organik sebanyak 10 ton/ha yang ditambahkan Trichocompos mampu menekan pertumbuhan Fusarium sp.

Pengendalian OPT pada demoplot menggunakan insektisida kimia, lampu perangkap, dan kelambu kasa menghasilkan $\mathrm{B} / \mathrm{C}$ berturut-turut sebesar 2,55; 2,76 dan 2,77.

\section{Saran}

Varietas unggul lokal Jawa Timur seperti Batu Ijo dan Rubaru dapat digunakan sebagai substitusi varietas.

\section{DAFTAR PUSTAKA}

Baswarsiati, L. Rosmahani, E. Korlina, E.P. Kusumainderawati dan D. Rachmawati. 1998. Pengkajian Paket Teknologi Budidaya Bawang Merah di Luar Musim. Prosiding Seminar Hasil Penelitian Komoditas Unggulan. BPTP Jawa Timur.

Teknologi Maju Budidaya Bawang Merah. Baswarsiati.wordpress.com. 24 April 2009. 
2010. Tiga Varietas

Unggul Bawang Merah Hasil

Kajian Bptp Jawa Timur. Badan

Litbang Pertanian. BPTP Jawa

Timur.

http://baswarsiati.wordpress.

com/2009/04/30/tiga-varietas-

unggul-bawang-merah-hasil-

kajian-bptp-jawa-timur/

Accessed date: April 17th, 2015.

T. Siniati, E. Korlina,

Abu. 2012. Teknologi maju budidaya bawang merah sesuai GAP (Good Agriculture Practices). Brosur BPTP Jawa Timur.

E. Korlina, D. Rahmawati, Z. Arifin, F.N. Azis, S.Z. Saadah, S. Fatimah. 2015. Kajian teknologi bawang merah dan cabai rawit merah ramah lingkungan pada lahan kering. Laporan Pengkajian. BPTP Jawa Timur (belum dipublikasi).

E. Korlina, C. Tafakresnanto, D.P. Saraswati. 2016. Rekomendasi Teknologi Spesisifik Lokasi Budidaya Bawang Merah di Jawa. Timur. BPTP Jatim.

Dinas Pertanian Provinsi Jawa Timur. 2014. Laporan Tahunan 2013.

Dinas Pertanian Provinsi Jawa Timur. 2015. Laporan Tahunan 2014.

Dinas Pertanian Kabupaten Nganjuk. 2015. Profil bawang merah di Kabupaten Nganjuk.
Dinas Pertanian Kabupaten Probolinggo. 2015. Profil bawang merah di Kabupaten Probolinggo.

Direktorat Jenderal Hortikultura. 2012. Laporan Tahunan 2011. Kementerian Pertanian. Jakarta.

Direktorat Jenderal Hortikultura. 2014. Pedoman Teknis Kegiatan Pengembangan Sayuran Dan Tanaman Obat Tahun 2014.

Duriat, A.S, T. Soetiarso, L. Prabaningrum. 1997. Penerapan Pengendalian Hama Penyakit Terpadu pada Bawang Merah, Puslitbanghortikultura.

Hadisoeganda, $\quad$ W.W., $\quad$ E. Wuryaningsih dan T.K. Moekasan. 1995. Penyakit dan hama bawang merah dan cara pengendaliannya. Dalam. Teknologi Produksi bawang merah. Puslitbanghort. Balitbangtan.Jakarta Hal 57 73.

Kementerian Pertanian. 2014.Rencana aksi Bukit Tinggi (Peningkatan Produksi Pangan)Bawang Merah dan Cabai, Kementerian Pertanian Direktorat Jenderal Hortikultura, disampaikan pada acara Raker Pendampingan Program Strategis Kementan 2629 Januari 2014 di Bogor.

Moekasan, T, L. Prabawaningrum, N. Gunadi, T. Adiyoga. 2010. PTT cabai merah dan bawang merah, Puslitbanghortikultura. 
Moekasan, T.K., R.S. Basuki, dan L. Prabaningrum. 2012. Penerapan ambang pengendalian organisme pengganggu tumbuhan pada budidaya bawang merah dalam upaya mengurangi penggunaan pestisida. J. Hort. 22 (1): 47-56.

Moekasan, T.K, Setiawati, W, Hasan, F., Runa, R, dan Somantri, A. 2013. Penetapan ambang pengendalian Spodoptera exigua pada tanaman bawang merah menggunakan feromonoid seks. J. Hort. 23(1):80-90.

Rosmahani, L., E. Korlina, Baswarsiati dan F. Kasijadi. 1998. Pengkajian tehnik pengendalian terpadu hama dan penyakit penting bawang merah tanam di luar musim. Eds. Supriyanto A.dkk. Prosid. Sem.Hasil Penelitian dan Pengkajian Sisitem Usahatani Jawa Timur. Balitbangtan. Puslit Sosek Petanian. BPTP Karangploso. 116-131.

Soeyamto, E. Korlina, Baswarsiati. 2001. Identifikasi dan saran pemecahan permasalahan hama ulat bawangmerah di Kab. Probolinggo. Lap. Hasil survey BPTP Jatim. Belum dipublikasi. 6 hal.

Sastrosiswoyo, S. 1996. Sistem Pengendalian Hama Terpadu dalam Menunjang Agribisnis Sayuran. Prosiding Seminar Nasional Komoditas Sayuran. Eds. Duriat, A.S dkk. Balai Penelitian Tan. Sayuran
Bekerjasama dengan PFI Komda Bandung dan CIBA Plant Protection. 15 hal.

Setiawati, W dan B.K. Udiarto. 2005. Pengendalian hama penting pada tanaman bawang merah dan pengendaliannya. Pelatihan TOT bawang merah. Balitsa Lembang.

Soetiarso, TA 2009. Teknologi inovatif bawang merah dan pengembangannya". Prosiding Seminar Nasional Pengembangan Inovasi Pertanian Lahan Marginal, hlm 293-324.

Sumarni, N dan R. Rosliani. 1995. Ekologi bawang merah . Dalam Teknologi produksi bawang merah. Eds. Soenaryono, $\mathrm{H}$. Dkk. Puslitbanghort, Litbang Pertanian. Jakarta. 12-17.

Udiarto, BK, Setiawati, W \& Suryaningsih, E. 2005. Pengenalan hama dan penyakit pada tanaman bawang merah dan pengendaliannya. Panduan teknis PTT bawang merah No 2. Balai Penelitian Tanaman Sayuran. Bandung. 